DOI: 10.1515/rpp-2016-0015

PhD in Pedagogical Sciences, Associate Professor, ANTONINA CHYCHUK

Bohdan Khmelnytskyi Cherkasy National University, Ukraine Address: 81 Shevchenko Blvd., Cherkasy, 18031, Ukraine

E-mail: tetyanna@ukr.net

\title{
NOVICE TEACHERS' INFUSION INTO PEDAGOGICAL ACTIVITY AT AMERICAN SCHOOLS
}

\begin{abstract}
The article deals with innovations used in the USA to assist novice teachers with adaptation to professional activity. It has been found out that the experience in implementing support programs for novice teachers and introducing the position of a mentor at schools is an extremely innovative system of novice teachers' adaptation in the USA. The analysis of pedagogical scientific works proves that novice teachers participate in different support programs: they attend seminars and conferences; they are offered to apply optimal approaches to student learning, attend lessons conducted by highly qualified teachers and analyze such lessons; a mentor is appointed for each novice teacher for the period of 2-5 years who assists him/her with writing personal professional development plan, lesson planning, teaches how to solve complicated pedagogical problems, analyze and define strong and weak sides of pedagogical activity that should be improved. Various support programs for novice teachers, organization and content of the educational process are different in American states, districts and schools, assist with improving knowledge obtained at university and serve as an intermediate stage between study programs and professional development during the whole period of teaching. We consider the abovementioned achievements to be worth further investigation. Moreover, positive aspects of such experience can be effectively implemented into the practice of secondary and high schools in Ukraine.
\end{abstract}

Key words: novice teacher, mentor teacher, pedagogical activity, innovation, support program, professional development, US experience.

\section{INTRODUCTION}

Novice teachers' support programs are an imperative component of American teachers' professional development, since professional training at colleges and universities cannot cover all the duties they are to perform during professional activity from the beginning. S. Birkeland and S. Johnson indicate that pedagogical practice is impossible without the support of more experienced colleagues (Birkeland, Johnson, 2003). It has been found out that knowledge and skills of $25 \%$ novice teachers do not correspond with professional teaching standards of the USA and more than 40 states allow teachers without basic teaching training to perform their professional duties in poor multicultural communities (InSites “A Support Network for Educational Change”, 2010). In addition, at the beginning of the $21^{\text {th }}$ century one third of novice teachers leave their position in the first five years and approximately $40-50 \%$ of teachers - the next seven years. According to R. Ingersoll in 2008 one second of school teachers had five and less years of experience caused by lack of quality professional training, insufficient knowledge of education standards and unwillingness to pursue teaching (Ingersoll, Merrill, 2010; Бондарук, 2013).

Quite often school districts and schools provide novice teachers with formal support that does not have a considerable influence on their professional development (Бондарук, 2013). 
J. Mundt emphasizes that novice teachers come across difficulties while organizing the educational process, i.e. lesson planning, working with students, teaching subjects. Moreover, they have to deal with syllabi, teach the subjects requiring those skills they do not possess yet and organize facultative lessons according to the needs of the community (Mundt, 1992; Андреева, 2000).

Taking into account the above it should be mentioned that over the last decades politicians and scholars have taken interest in development of novice teachers' support programs. In the USA graduate teachers are also provided with opportunities for professional development in the first years of professional activity so that they may strengthen obtained professional knowledge, skills and abilities. Nowadays, more than $80 \%$ of teachers participate in such programs as opposed to that of $40 \%$ in the 1990 s of the $20^{\text {th }}$ century (American Association of State Colleges and Universities, 2006).

\section{THE AIM OF THE STUDY}

The aim of the article consists in reviewing innovations used in the USA to assist novice teachers with adaptation to professional activity.

\section{THEORETICAL FRAMEWORK AND RESEARCH METHODS}

In the USA particular attention is paid to the support of novice teachers. Thus, such scholars as S. Birkeland, O. Brown, W. Fuller, R. Ingersoll, J. Johnson, S. Johnson, K. Ryan, E. Seifert, P. Simone, M. Strong and many others have studied the matter in their works.

To achieve the set aims such methods as analysis, synthesis, generalization and systematization have been used.

\section{RESULTS}

New Teacher Center (NTC) at the University of California (Santa Cruz) is considered to be one of the leaders in organizing teachers' learning at the primary stage of professional development in the USA. NTC collaborates with school districts and pedagogues in over than twenty states (California, Texas, Alaska, Florida, Wisconsin and others) elaborating programs for novice teachers that correspond to education aim of each district. It should be mentioned that novice teachers in twenty-seven states are to take part in support programs the duration of which can vary (Colorado - 1-3 years, Wisconsin 5 years). In Alabama and Alaska they are not obligatory, although most of educators are willing to participate (New Teacher Center, 2012; Бондарук, 2013).

Education Technologies Center (ETS) in Princeton (New Jersey) organizes support programs for novice teachers, too. The center aims at developing tests to assess novice teachers' qualification at the beginning of pedagogical activities in most states. Praxis Series $^{\circledR}$ is the most popular one targeted at assessing professional knowledge and skills of novice teachers and consists of two test groups.

Praxis $I^{\circledR}$ Pre-Professional Skills Test $\left(\right.$ PPST $^{\circledR}$ ) checks basic erudition: general knowledge of mathematics (digits and operations with them, algebra, geometry, measure system, analysis and data relativity) and language skills (grammar, language structure, word order) every teacher should possess.

Praxis II ${ }^{\circledR}$ contributes to the assessment of teachers' general and specific knowledge of subjects they teach; general pedagogical skills of primary, secondary and high school teachers; pedagogical knowledge in one of the fields - teaching methodology, mathematics methodology, English or natural sciences methodology (Бондарук, 2013).

So, Praxis tests developed by Education Technologies Center (ETS) in Princeton help to assess novice teachers' level of basic knowledge, subject knowledge and teaching methodology in most American states. Some universities organize internships for teachers. 
Thus, after graduating from Oregon University every novice teacher works under the supervision of an experienced pedagogue there. Teachers who completed three-year internship are more competent and methodically knowledgeable than those who did not participate in such programs as they are undergoing both the final stage of special training and the initial stage of practical professional activity for three years.

Such novice teachers' support programs turned out to be very effective in the USA. $75 \%$ of teachers-graduates of Oregon University work in the same districts where they had teaching practice.

In rural American districts Rural Teachers Clubs were established to ensure better adaptation of novice teachers through moral and methodical assistance. For example, teachers who work far from home organize meetings in their spare time there. Every month novice teachers share experience, discuss urgent pedagogical problems that contributes to their professional development. Moreover, such meetings can be organized for leisure, i.e. during holiday season so that teachers may enjoy informal atmosphere and, thus, it strengthens relations within the community and improves novice teachers' pedagogical activity. They imply:

At many American universities novice teachers' support programs were developed.

- university lecturers' assisting novice teachers with lesson planning and consulting them about teaching methodology;

- measures for novice teachers' activity coordination held by state education departments.

It should be noted that at US schools there is a position of a teacher-mentor who supervises work of novice teachers at the beginning of their professional career to foster their infusion into pedagogical activity according to support programs established by school administrations. Over a hundred of teachers in major school districts participate in such programs. These districts hire several mentors assisting 10-15 novice teachers each. Rural schools hire only 3-4 novice teachers which is why there are no mentors exempt from main duties. Experienced teachers also provide novice teachers with support and that is included into their teaching loads. However, most of school districts and large rural schools provide for positions of both district and school mentors. We have singled out their duties.

A district mentor is to:

- take part in a two-week session at college before the academic year starts and ensure school mentors' participation;

- hold a general meeting of mentors and novice teachers before the academic year starts;

- organise 6-8 seminars on novice teachers' advanced training and ensure the attendance of 6-10 lessons conducted by every novice teacher during the academic year;

- hold meetings with school mentors aimed at discussing novice teachers' progress;

- strengthen technical connection of schools with methodical centers;

- present information about cooperation with novice teachers to the community as well as reports on the progress of college programs. District mentors spend most of their working time associating with school mentors and less time with novice teachers.

A school mentor is to:

- constantly supervise novice teachers' work and provide them with support;

- take part in six-day courses before the academic year starts and a general meeting of school mentors and novice teachers held by colleges;

- provide novice teachers with information about school and school district;

- participate in preparation and holding of seminars for novice teachers; 
- attend lessons conducted by novice teachers;

- meet with a district mentor and inform him/her about the progress of the program.

Teachers applying to the position of a district mentor should undergo a 50-hour training conducted by instuctors at local universities to clear up the role of a district mentor, peculiarities of his/her cooperation with school mentors and novice teachers (Андреева, 2000).

Witin our paper we would like to provide examples of application of support programs for novice teachers.

In the state of Connecticut Teacher Education and Mentoring Program (TEAM) plays an important role in improving the teaching profession. It is one of the most significant programs aimed at teacher professional development in the USA designed for two years and including such forms and methods of the educational process as seminars, conferences, independent work, teaching under the supervision of a mentor, lesson observation and discussion, report writing, group work, tutorials with a mentor. According to the support program the educational process consists of 5 modules. Modules are based on main learning statements of TEAM program (TEAM: Teacher Education and Mentoring Program, 2016).

The statements provide for responbilities of teachers. They are to demonstrate professional knowledge of reading, writing, mathematics; apply verbal, nonverbal and technological communication to the educational process; use information and communication technologies (ICT); exercise analytical skills to teach students how to solve different issues, analyze and discuss latest researches.

According to TEAM program novice teachers study such learning modules:

- development of skills needed to create positive learning environment in the classroom for successful learning of students of different nationalities; development of novice teachers' correspondent standards of conduct influencing productive learning environement;

- active learning planning, use of sources positively affecting development of critical thinking and creativity;

- improvement of active learning methods to achieve the best results in students' learning; use of ICT; cooperation with students during the educational process to increase students' progress;

- asessment of knowledge of students with different cultural, lingual, ethnic and gender identities to improve the educational process;

- development of teacher professional responsibility in the state of Connecticut.

During the first year of the program novice teachers study 2 modules and during the second year -3 . Learning by the program analyzed is carried out under the supervision of a mentor and is directed at improving novice teachers' knowledge of the subject, enhancing their pedagogical mastery during $8-10$ weeks in each module:

- during the weeks 1-3 novice teachers study optimal pedagogical experience, together with their colleagues identify weak sides of their own pedagogical activity, formulate directions for their professional development;

- during the week 4 novice teachers study thematics of conferences, seminars and create personal professional development plan;

- during the weeks 5-8 novice teachers discuss positive impact of learning on teaching and students' progress with their mentors;

- during the weeks 9-10 (the final stage of the module) reports (3000 words) on positive changes in novice teachers' pedagogical activity should be presented to be analyzed by the district committee (Бондарук, 2013). 
Main statements of 5 learning modules of TEAM programs approved by the Connecticut State Department of Education in 2010 influence the quality of the educational process carried out according to the support program for novice teachers aimed at developing professional knowledge and skills, advancing professional qualification and obtaining Professional Education Certificate (Advanced) (Бондарук, 2013). The program is popular in 250 school districts of the state and defines the duration of training for different categories of teachers. For example, teachers of the first category are to study 5 modules for 2 years (English, mathematics, biology, chemistry, physics, Earth sciences, basics of natural sciences, valeology, special education, primary education, secondary education, history, social sciences, art, music, gymnastics, foreign languages) (TEAM: Teacher Education and Mentoring Program, 2016).

It should be mentioned that if the activity of a novice teacher does not corespond to learning regulations of the TEAM program, he/she is not allowed to advance his/her qualification and consequently teach (Бондарук, 2013).

So, mentors assist novice teachers with defending their learning modules and their obtained results are included into the personal professional development plan, final module assessments aimed at identifying the level of teachers' professional development. In her thesis "Training, Adaptation and Professional Advancement of Rural Teachers" G. Andryeyeva characterizes a support program for novice teachers developed in the Clinton school district based on the teacher education faculty at Wilmington College and implemented into rural schools in the Southwest Ohio. The program comprises 3 rural school districts of 4800 students and 296 teachers. The position of a school mentor based on a model of a district mentor was created so that he/she could coordinate activities of novice teachers in each rural school and become a facilitator between mentors and novice teachers.

This program is rather innovative as it provides for the use of electronic means of communication that significantly facilitates information exchange between distant areas (Odell, Ferraro, 1992; Андреева, 2000).

Another example is the support program launched by Arkansas State University that involves 4300 students. In 1990 Regional Education Center was founded there. Currently it embraces 27 rural areas and is funded by the Ross Fund, the Rockefeller Foundation and local budget. The Center and the University develop and implement pilot programs for all the novice teachers of the district.

The responsibilities of the Regional Education Center are to facilitate students' transformation into teachers; to encourage novice teachers to engage in pedagogical activity; to appoint mentors for novice teachers; to appoint school administration and center representatives to observe novice teachers' practice; to provide both novice teachers and mentors with a scholarship to participate in a one-year support program.

Mentors depending on the efficiency of the Center representatives determine the content of lessons; University professors organize lessons, provide for technical means and classrooms. It should be mentioned that only 29 participants registered when the program was first launched. Nowadays over 60 novice teachers annually participate in the program and discuss urgent needs together with professors. In addition, mentors also prepare presentations that are later being discussed by all the participants. Such sessions are held at least 9 times a year.

According to the statute of the Regional Education Center mentors are to take part in the sessions; to hold a meeting with novice teachers no less than once a week; to encourage novice teachers to attend his/her lessons; to attend lessons conducted by novice teachers; to keep a weekly journal to reflect on novice teachers' results. 
Novice teachers are to take part in all the sessions organized by the University; to attend lessons conducted by mentors and experienced teachers; to invite mentors to attend their lessons; to keep a weekly journal to note the information needed for the report for the Regional Education Center.

It should be mentioned that there is a consulting council at the university. It solves all controrversial issues emerging within support programs for novice teachers. It involves the dean of the teacher education faculty, two representatives of the Regional Education Center, the headmaster of primary school, the headmaster of secondary school, two mentors, two novice teachers. The council becomes acquainted with information from district schools and suggest ways to facilitate the procedure of providing support for novice teachers. At many American schools such cooperation between school and university teaching staff is quite popular. It should be noted that after completing such support programs almost all novice teachers decide to work at schools as they are feeling the belonging to the teacher profession and have become more confident (Hersh, Stroot, Snyder, 1992; Андреева, 2000).

\section{CONCLUSIONS}

The experience in implementing support programs for novice teachers and introducing the position of a mentor at schools is an extremely innovative system of novice teachers' adaptation in the USA. We consider the abovementioned achievements to be worth further investigating. Moreover, positive aspects of such experience can be effectively implemented into the practice of secondary and high schools in Ukraine.

The analysis of pedagogical scientific works proves that novice teachers participate in different support programs: they attend seminars and conferences; they are offered to apply optimal approaches to student learning, attend lessons conducted by highly qualified teachers and analyze such lessons; a mentor is appointed for each novice teacher for the period of 2-5 years who assists him/her with writing personal professional development plan, lesson planning, teaches how to solve complicated pedagogical problems, analyze and define strong and weak sides of pedagogical activity that should be improved.

Various support programs for novice teachers, organization and content of the educational process are different in American states, districts and schools, assist with improving knowledge obtained at university and serve as an intermediate stage between study programs and professional development during the whole period of teaching.

So, having analyzed support programs for novice teachers in the USA we can conclude that the educational process at Ukrainian schools requires development of such statements: implementation of personal professional development plan for novice teachers, mentoring, organization of novice teachers' advanced training.

\section{REFERENCES}

1. American Association of State Colleges and Universities. (2006). Teacher Induction Programs: Trends and Opportunities. Policy Matters, Volume 3, No 10, 4 p.

2. Educational Testing Service (ETS). (2016). About the The Praxis Series ${ }^{\mathbb{B}}$ Tests. Retrieved 13.05.2016 from : http://www.ets.org/praxis/about.

3. Hersh, S., Stroot, S., Snyder, M. (1992). Mentoring Entry Year Teacher: a Modal for Rural Communities. The Rural Educator, Volume 15, No 3, pp. 15-16.

4. Ingersoll, R., Merrill, L. (2010). Who's Teaching Our Children? Educational Leadership, No 67 (8), pp. 14-20. 


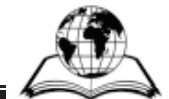

5. InSites "A Support Network for Educational Change". (2010). Creating a Teacher Induction Program. Frisco, CO : InSites, 45 p.

6. Johnson, S. (2003). Pursuing a Sense of Success: New Teachers Explain Their Career Decisions. American Educational Research Journal, No 40 (3), pp. 581-617.

7. Mundt, J. (1992). The Induction Year - a Naturalistic Study of Beginning Secondary Teachers of Agriculture in Idaho. Journal of Agricultural Education, Volume 33, No 2, pp. 18-23.

8. New Teacher Center. (2016). Effects of Mentoring on Teaching Practice. Retrieved 13.05.2016 from : http://www.newteachercenter.org/impact/practice.

9. Odell, S. J., Ferraro, B. P. (1992). Teacher Mentoring and Teacher Retention. Journal of Teacher Education, No 43, pp. 56-57.

10. TEAM: Teacher Education and Mentoring Program. (2016). About Us. Retrieved 13.05.2016 from : http://www.ctteam.org/?page_id=2.

11. TEAM: Teacher Education and Mentoring Program. (2011). The Teacher Education and Mentoring (TEAM) Program Guidelines 2011-2012. Retrieved 13.05.2016 from : http://www.ctteam.org/wp content/uploads/2011/11/TEAM_GUIDEZINES_11-12.PDF.

12. Андреева, Г. Б. (2000). Подготовка, адаптаџия й повышение квалификации сельских учителей [Training, Adaptation and Professional Advancement of Rural Teachers]. Thesis for $\mathrm{PhD}$. Московский государственный открытый педагогический универстет, 154 р. (in Russian).

13. Бондарук, Я. В. (2013). Організація навчального процесу в системі підвищення кваліфікації вчителів у США [Organization of the Educational Process in the System of Teacher Advanced Training in the USA]. Thesis for PhD. Черкаський національний університет ім. Б. Хмельницького, 209 р. (in Ukrainian). 